\title{
1. \\ InTROduction: Political Spaces \\ AND MO(VE)MENTS OF RESISTANCE
}

This book is about politics in Israel/Palestine. Politics, however, is too comprehensive a concept, because politics is in some sense everything and everywhere. There is politics at home, in the family, at work, among colleagues and managers. In the sports club, the homeowners association, and worker committee; on municipal, provincial, state, and national levels, as well as international forums.

Politics is not all about large-scale and complex systems. It exists wherever two or more people are part of a shared activity and a decision about that activity affects all of them. Politics refers to the process of decision making and implementation: who makes the decision? Do they take into account those affected by it? This begs the question of power relations and formal and informal decision making process. Who has power over whom? Can one person or group take a decision that affects the other unilaterally, imposing their will, or do those affected also have some power to oppose the decision and influence it? Is there a process of deliberation and dialogue, or does the decision maker have the power to ignore the interests, wishes and demands of the affected? Is the process of decision making institutionalized, namely formally regulated by consensual rules of the game? How do these rules affect the decisions made and the chances of those affected to shape the decision? How do the affected react when they are ignored? Do they accept the decision, protest or stop taking part in the shared activity, group, organization or institution ${ }^{1}$

Politics is about the dynamic relations between those who make decisions and the actions and reactions of those affected by them. When some form of recognition and deliberation between the decision makers and those affected takes place formally or even informally, and the affected can influence and monitor the decision makers and change their

1 On the options to accept the decision, protest or leave, see Hirshman (1970). 
decisions, we can talk about an interactive deliberated decision-making process. Again, the interactivity of the political process does not depend on the size or complexity of the shared framework, or on the existence of formal rules of the game. When decisions are made while ignoring those affected we can talk about unilateral imposed processes.

Scholars who studied political processes on the nation-state level suggested a distinction between democratic and authoritarian regimes (Moore, 1965; Rustow, 1970; O’Donnell and Schmitter, 1986; Przeworski, 1991; Linz and Stepan, 1996). The theoretical framework of the research presented here attempts to go beyond the democracy/autocracy dichotomy, and comprehend dynamic political processes of change on the macro-political level of nation-states. The intention is to focus on dynamic processes of political change that exceed the scope of this schematic dichotomy, mainly in an attempt to discover the capacity of dominated social groups to mobilize, resist, and influence unilaterally imposed decisions. I investigate here dynamic political processes both with and without democratic rules of the game, and also examine the capacity of political power holders in formal democracies to ignore citizens' demands. In order to comprehend these complex political dynamics and be able to critically analyze formal democratic regimes, I have developed the concept of political space (Grinberg, 2010). Although my initial insights originated in my study of Israeli-Palestinian relations (Grinberg, 2010), I intend to propose here a theoretical framework of political dynamics useful for comparative analyses and critiques of a broad range of political contingencies, cases, and events.

The concept of political space refers to the peaceful containment of social conflicts by means of recognition and representation. Political space is dynamic, can be opened and closed, and was initially designed to comprehend the changing policies of recognition and rejection of Palestinian demands by the Israeli power holders in the years 1988-2006 (Grinberg, 2007, 2010, 2013a). This book is part of a new research project designed to expand the analytical framework of dynamic political processes by comparing a series of case studies of different and opposed reactions of dominant power holders to resistance by various dominated social forces, including class, ethnic, national and civil society protests. The initial concept of political space was based on the dichotomy of politics/violence, interpreting violence as the means to close political spaces, and politics as the way to open them for containing conflicts by 
recognition, representation, negotiation and compromise. In the present book I seek to expand the concept of dynamic political spaces by going beyond the politics/violence dichotomy, aiming to comprehend the more nuanced political dynamics occurring between instances of violent repression and vicious cycles of violence and counter-violence, on the one hand, and successful cases of containment of social conflicts by recognition, representation, negotiations and compromise on the other.

The situations and cases analyzed here focus mainly on the more subtle strategies of domination by power holders, the non-recognition or misrecognition of the needs and rights of dominated groups and the power to ignore the fundamental equality between human beings. This is not physical violence exerted on the dominated groups, but what Bourdieu (1992) has termed symbolic violence, namely the capacity of the dominant to ignore, non-recognize or misrecognize the subordinated. In order to oppose this form of domination, people who are ignored must actively demonstrate their physical presence in order to gain visibility and recognition of their needs and wills, demanding to be taken into consideration.

I suggest using the term "resistance" to refer to the proactive demonstrations of presence by subordinated social forces seeking recognition and representation in the decision-making process. The dynamics between the symbolic violence of the dominant and the physical resistance of the dominated are at the theoretical focus of this research plan. It is based on the analysis of seven different cases of resistance movements on particular political junctions in the history of Israel. The comparative research method is designed to learn about various forms of resistance mobilization, and different repertoires of struggle against dominant powers. The research is also designed to learn about the various reactions of power holders, both political actors and state institutions, and their repertoires of contention.

The Israeli case is so rich in cases of proactive resistance and reactive responses by the dominant powers that it seems an almost ideal laboratory for building social theory. I start with an anti-colonial revolt of the mixed Arab-Jewish civil society against the British Mandate in Palestine in 1931 and continue with ethnic riots (1959) and a working-class strike wave (1960-1965) during the formal democratic regime of the State of Israel in 1948-1967. During the period of the dual democratic-military regime established in Israel/Palestine after 1967, I compare four cases 
of resistance: ethnic riots (1971) working class mobilization (1980), national uprising against military occupation (1988-1992) and "Occupy"style movements against neo-liberal economic policies (2011). After analyzing each case I compare them in Chapter 9, suggesting some theoretical generalizations. In this introduction I present the theoretical concept of dynamic political spaces as developed in my previous investigations, and proceed to explain how the resistance of the dominated, oppressed and non-recognized contributes to theoretical development.

\section{ON Politics AND Violence}

Hannah Arendt criticized scholars like von Clausewitz, Weber, and C.W. Mills, who assumed that violence is part and parcel of political power, an inseparable continuum (Arendt, 1969: 8, 35-6). Arendt calls "power" what I call here, for the purpose of clarity, "political power," and she clearly distinguishes between them: "Power and violence are opposites; where the one rules absolutely, the other is absent. Violence appears where power is in jeopardy" (56). According to Arendt, the main source of confusion between the two forms of domination is that they usually appear together as forms of state power. However, they differ significantly: political power is based on dialogue and consent, while violence is a unilateral imposition. Violence can destroy political power, but cannot build it, and if a ruler rules exclusively through violence without any form of political consent, the use of violence becomes intimidationused to deter political opponents.

Political spaces of representation are opened when authoritarian ruling elites recognize their inability to continue ruling unilaterally due to the increasing violence needed in order to remain in power. When rulers opt to recognize some claims of the dominated groups and open dialogue with their representatives, the process is defined as democratization or transition to democracy (Rustow, 1970; O'Donnell and Schmitter, 1986; Przeworski, 1991; Linz and Stepan, 1996). Democratization has occurred in very different contexts and paths (Tilly, 1995), but it usually entails the institutionalized opening of political space for representation, negotiation, and compromise. However, the concept of dynamic political spaces here suggested also seeks to explain why institutionalized democracies sometimes fail to represent claims and opin- 
ions in civil society, and also to contain social conflicts. In these cases democracy can be fake, an illusion (O’Donnell, 1992, 1996).

Political space as a symbolic field of representation is necessary when large social groups and state apparatuses cannot be physically present in the process of decision-making, and sides in a conflict must be mediated by political actors representing them. In other words, while violence is a physical act of presentation of coercive power, politics is a symbolic act of representation of social groups and organizations. Violence can be effective only if a concrete group of people are ready to exercise it (Arendt, 1969; Mann, 2005), while politics is exercised in the absence of the social group, which is imagined and constructed by the political leaders who represent it, act on its behalf and wish to continue being its spokespersons (Bourdieu, 1992).

The crucial factor in the use of physical violence is the existence of social forces ready to use it against the other, especially when "they" are considered not part of "us." Democracy and the "nation-state" might become violent and dangerous because it excludes "internal others" and in some specific circumstances constructs them as "internal enemies," building the legitimacy to use violence against them, and the conviction of the soldiers that by obeying orders they are defending the nation (Mann, 2005).

The distinction between politics and violence helps clarify the political role of the military apparatus, namely that its action or inaction in the internal power struggle always has political implications. Tilly (1992) shows that state makers expand their territorial control and demarcate borders, extracting material and human resources from the population under their dominion. By so doing, the military defines the subjects of the state, and creates "internal" space where the state's civil apparatus can extract material resources from the "internal" population. The extraction of resources to finance the military and war forces the state's civil apparatuses to negotiate with local populations, open political space, and democratize (Tilly, 2007). In my previous work I have argued that the military elites become political actors, whatever attitude they adopt towards struggles between dominant and dominated groups. If the military uses violence against the population in support of the rulers, it closes space to political representation and mediation; if it refuses to, it creates a balance of power that facilitates the opening of political space (Grinberg, 2008, 2010, 2013a). 
When the military only protects the state's external borders and avoids violence against citizens, it is considered apolitical, and when it intervenes in internal power relations or takes power directly, it is seen as a political actor. ${ }^{2}$ In both cases, however, the military shapes the political arena, and this is the most crucial factor in creating the two fundamental preconditions for opening political space: the military demarcates the borders of the state that define the shared identity of potentially equal citizens, and facilitates a balance of power when it does not use violence against the dominated population. The contradiction between violence and politics takes the form of alternative options between military repression and the opening of political space for representation of dominated groups (Grinberg, 2013a).

\section{Political Space}

Although physical borders of states and symbolic boundaries of national communities are the frameworks that contain political space, they are also signals of violence. They are usually evidence of use of violence in the past-in war and colonial and imperial expansion governed by the exclusionist character of national movements - and in the present they impose limits on freedom of movement and the civil rights of individuals and groups (Balibar, 2004). At the same time, however, the existence of recognized borders facilitates the containment of conflicts within them because borders open the possibility of claims to formal equality between state subjects, the peaceful expression of demands, and the organization of dominated groups.

Whereas politics is based on recognition, representation, and dialogue, violence is based on non- or misrecognition of the Other, physical presentation of coercive power, confrontation, and unilateral dictation by the powerful. Both are forms of state power relations, but represent competing and frequently contradictory principles of conflict management.

To comprehend the tendency to use violence and historical moments when violence is perceived to be illegitimate, ineffective, or undesirable, I suggest framing the question within a dynamic concept of political 
spaces. Usually, the meaning of the concept "political space" is taken for granted; it is used intuitively without an explicit definition or conceptualization. Political space is not a physical area but a social construct, a symbolic field of representation (Bourdieu, 1992) within a specific sphere of power relations, distinct from civil society and the state (Linz and Stepan, 1996), that frames a dynamic arena of contestation and containment of social conflicts within constantly changing opportunities (Tarrow and Tilly, 2007; Tarrow, 1996; Collier and Collier, 1991). Political spaces of representation may be opened or closed in the political arena, which is differentiated from social forces and state institutions, but is framed and determined by them. Struggles over the opening of political space take place in the political arena, mainly through the contestation of political actors, but social and state actors also take part in shaping the political arena. This book aims to expand our understanding of the dynamic opening and closure of political spaces by analyzing actions by political, social and state actors and the interactions between them.

The concept of political space suggested here is not the geographic space, or the territorial dimension of the state. The term political space, as used here, refers to the symbolic representation of social conflicts in the political arena which are mediated by political actors and framed "between" the state institutions and the civil society. The political arena (or field) is framed by the state and civil society, but is not autonomous - and its dynamic and very existence are shaped and reshaped by changes in power relations between the state and civil society.

The political arena is a symbolic field where political actors can suddenly appear and disappear, and the rules of the game can be drastically changed or revoked. Political actors may open or close political spaces claiming to be representatives of concrete social forces and speaking in their name; they seek to promote the interests of these forces, but are completely dependent on public support and the state's rules of the game that constrain their action. This lack of autonomy is a byproduct of the fact that the state and civil society are not only symbolic fields, and when social forces remove their support from specific political actors or if the state legally prevents their action, political space might close, old political actors might disappear and the political arena of mediation might be suspended by unilateral regimes. Even when the political arena is institutionalized and consolidated, political actors might be removed 
from their positions, and new political actors may take their place. As discussed throughout this book, the threat posed by new political actors leads incumbent actors to try to close political space to new identities, agendas, and actors. Here lies the puzzle of the present research: How can old political actors maintain their power and prevent representation within or without the democratic rules of the game.

Political actors seek to bridge tensions and conflicts at two levels: (a) between the state and its civil society, and (b) between dominant and dominated social groups within civil society. These tensions are mediated in the political arena by collective imaginations of who "we," the people, are and how the state's concrete policies are presumed to serve civil society. The political field's symbolic aspect facilitates this by imagining social forces as "groups" with shared identity and needs, as well as imagining the collective national identity of the entire civil society. Imagination is crucial in politics also in order to build visions of more desirable futures and contested interpretations of the past and present realities. In the political field, reality is constructed by symbolic means such as narratives, discourses, and myths.

\section{Political Field, Arena ANd Actors}

Bourdieu conceives the political field as an autonomous symbolic field where competing actors vie for power. These actors' struggles are homologous of struggles in other socioeconomic fields, and by their speech and actions, political actors create the social group that cannot speak for itself. The political field appears historically as the result of the construction of bureaucratic fields of power, in tension with and differentiated from the crown. ${ }^{3}$ The politician's power is symbolic and, by way of delegation, he can silence other group members because he speaks in their name and has a vested interest in continuing to speak for them (Bourdieu, 1992: Ch. 9).

The concept of political space suggested here shares Bourdieu's definition of the political field as a symbolic field of representations of social groups, but the most important difference concerns the assumption that the political field is autonomous. On the contrary, it is my argu- 
ment that one of the most salient features of the political space here proposed is its lack of autonomy from other fields, because it is framed by and dependent on the state and civil society. This is also the reason for the tension with other fields and the potential absence of homology. It explains why political space can suddenly be opened and closed by critical political events. Civil society has relative autonomy and its constant dynamics shape the political field, affecting who may claim to represent it. The organization of civil society has the power to affect the political field, remove politicians who disappoint the forces they claim to represent, and support new speakers, opening political space and transforming the political arena (Cohen and Arato, 1994). In other words, it is not only the political actor who creates a social group, but social groups who are able to support or remove political actors. The dynamic interrelations between political actors and the social groups they claim to represent, and the dependence of the former on the latter, are crucial to the concept of political space and particularly to the questions raised by the present research project regarding social resistance to power.

These interrelations are also at the core of Linz and Stepan's (1996) conceptualization of "political society" as distinct from civil society, but in constant interaction with it. Political society bridges civil society and the state, and political parties have a crucial role to play in the process of democratization. The distinction between these three levels is critical to the consolidation and smooth functioning of democracy. The organization and active participation of civil society is vital to guarantee the role of political society as representative of social interests. The three levels - state, society, and politics - are distinct spheres of action: the state shapes political society and the relations within civil society, while political society mediates the conflicts within civil society and between it and the state through state apparatuses and policies. Civil society is the sphere of organization and presentation of social interests, agendas, and ideas by social actors-organizations, movements, and individuals-while politics is the sphere of political actors representing absent social groups and compromising in their name given limited state options and resources.

I refer to the political sphere, field, or arena as Linz and Stepan (1996) interpret the political society that bridges civil society and the state, which mediates conflicts between social forces. However, political society is formally organized and relatively stable when democracy is 
consolidated, while political spaces are in a constant dynamic: they may be closed even by the political actors in response to mass mobilizations by civil society. I argue here that the tension between civil and political societies is precisely due to the political field's lack of autonomy, and the concern of political actors for their future position and power. State and political actors can engage in conscious manipulation in an effort to demobilize civil society when they sense a threat to their power by the dynamic that helps open political spaces. This is why political spaces are dynamic and unstable, while civil society's demands might be neutralized by state and political actors seeking to maintain their power. These dynamics between civil society actors and mass movements, and the reactions of political and state actors, is the subject matter of the present research. In other words, political space is a dynamic concept: it may be opened for representation and containment of social conflicts but also closed even by consolidated democratic regimes and institutionally differentiated political societies.

The fluctuations of civil society mobilization under changing structural conditions and conjunctures have been extensively investigated by researchers of social movements who proposed the dynamic concept of political opportunities structure (POS) (Tarrow, 1998; McAdam, Tarrow and Tilly, 2001; Tarrow and Tilly, 2007). The concept of dynamic opening and closing of political spaces incorporates the idea of the constantly changing structure of opportunities. However, the POS approach focuses on opportunities open to civil society movements and organizations to mobilize social groups and shape state policies, while the focus of political space is on the political mediation between civil society and state policies and among different social groups. The analysis of dynamic political spaces focuses on political actors and their relations with civil society and state policies in changing national and international contexts. It examines the ways in which these political actors interpret and re-present social demands, or opt to ignore them due to their own interest in maintaining their power positions. ${ }^{4}$

The political articulation between civil society and the state and their multiple dynamics and variations has been the focus of Collier and Collier (1991) in their comparative study of the transition of Latin

4 This is in line with recent interest in the processes of grievance formation, which are often neglected in POS literature (Pinard, 2011). 
American states from democracy to authoritarian rule and back. In their approach, political sphere is an arena of contestation, articulation, and containment of social conflicts. The greatest challenge to the capitalist regime is the democratic incorporation of the working class, while the constant dynamic of democratization and de-democratization is explained by changing global and local contexts, and the specific ways in which political parties incorporate trade unions and the working class.

The dynamic analysis of the political arena proposed by Collier and Collier (1991) is very close to my concept of dynamic opening and closing of political space, including its path-dependent aspect and the option of total elimination of the political arena by dictatorial regimes. The main difference is that according to them, civil society is mainly characterized by class conflict and politics is analyzed mainly by the party-trade union institutional links in a situation where the state's borders and national identity are not contested. The concepts of political arena and dynamic opening of political spaces I suggest here include other forms of social conflict precipitated by colonial and military expansion, and also conflicts between national, ethnic, and religious groups. The analytical concept of dynamic political spaces aims to include also violent repression and closure of political spaces within the multiple complexities of colonial and settler societies. However, in this book I focus on relatively contained and peaceful forms of symbolic violence by dominant elites and resistance movements of subordinated social forces.

\section{IMAgined Communities, IMAgined Democracy, AND SETTLER SOcieties}

The literature of transition to democracy has emphasized citizens' shared identity as a precondition for democratization (Anderson, 1999), but the existence of frameworks of containment (sovereign states and national identities) has been taken for granted. Stepan (2001, Ch. 9) has properly commented that despite the extensive simultaneous research of transitions to democracy and the emergence of nations, these two important research projects have almost completely ignored each other. This theoretical lacuna is especially surprising because nationalism and democracy emerged almost at the same time and place-after the decay of dynastic orders and the development of capitalism in eighteenth- 
century Europe. Democracy is based on the idea of popular sovereignty over the state, while national communities are defined vis-à-vis state authorities, either as the sovereign people of an already established state, or a as claims of subjugated population for independence from and popular sovereignty over imposed imperial and colonial power.

Democracy institutionalizes the procedures to govern state apparatus by "the people," while the borders of the state and "the people" are taken for granted and not as a matter of contestation and conflict. As Offe correctly commented, "The people cannot decide who is the people" (1998: 116). Liberal approaches to democracy assume all citizens constitute "the people" while "organic" approaches define the nation in cultural and historical terms, and in so doing exclude a portion of the citizens. The symbolic boundaries of the people are, in several contexts, a matter of democratic struggle to open political space of representation to excluded citizens. When a subjugated group is empowered by internal or external factors, it may organize and claim its recognition and inclusion as equal citizens.

The most glorified recognized struggles for democratization are those of social groups considered part of the nation, like the struggles of the working class and suffragettes for recognition of their equal rights to vote and be represented. These were struggles demanding the opening of the political space of representation, and even when some violence was used it was a means to achieve recognition, equal citizenship and representation. However these groups were symbolically included within the boundaries of the nation, so the change demanded was only a matter of recognition of formal equality, rather than the re-imagining of the nation's boundaries. Thus, social conflict was contained by opening political space for representation, facilitated by the democratic rules of the game.

Struggles to open political space to groups defined by the national borders as not belonging to the nation were much more violent, and in several cases ended in ethnic cleansing and genocide. Mann (2005) shows that democratic regimes can be aggressive and brutal toward excluded social groups even more than non-democratic regimes-whether colonial, dictatorial or communist. In cases of symbolic exclusion from the nation, democracy becomes the problem: if it is "the people" who rule, and non-nationals are recognized as legitimate equal citizens, they can shape politics and state institutions and even become the rulers. In non-democratic regimes, there is no such danger because the political 
arena is not the bridge between the state and civil society, and there is no need for extremely violent forms of repression like ethnic cleansing. In a similar line of thought, Zakaria (1997) argues that for cultural minorities, liberalism is more crucial than democracy and a liberal dictator is preferable to an illiberal democracy. In both cases, political space for minority representation is closed, but democracy views minorities as a "threat" due to their potential claim for representation, and becomes more aggressive and repressive toward them. On the other hand, authoritarian regimes that formally prevent the political arena of mediation from becoming formally institutionalized may open other channels of mediation and dialogue with civil society, including minorities.

Democratic regimes obviously claim to be open, representative, and nonviolent; when they become violent it is justified as self-defense against an "existential threat." Elsewhere, I have emphasized the close linkage between democracy and the national community by using the term "imagined democracy" (Grinberg, 1999). Every democracy is imagined, and imagined twice: once because it imagines the national community, "the people," and again because it imagines elected political actors as if they actually represent parts or divisions and conflicts among "the people." Both "the people" and its parts are imagined and represented by parties. However, a working democracy, able to contain social conflicts by peaceful mediation and dynamic opening of political spaces of representation, is assumed to realize and materialize the imagined "ruling people" by implementing policies promised by elected officials. When these disappoint their constituencies, civil society has the potential power to make democracy real: it can mobilize, express discontent, and change the government. This is precisely the dynamic of opening political space legally framed by the democratic rules of the game. However if some group is formally or informally denied access to state power, recognition, or equal human and political rights, democracy becomes not only imagined but illusory, because it cannot be realized and cannot contain social tensions by representation. This book focuses on the Israeli imagined democracy, the obstacles to representation of various subordinated social forces, and the resistance movements that emerged claiming recognition and representation.

Israeli imaginary democracy's historic origin is the settler political project. Settler societies are the clearest cases of imaginary democracies that formally close political spaces of representation to others, in 
this case non-settlers. Settler societies generally established democratic regimes for European migrants, but denied equal rights to the other native and non-native populations. They occupied the "new" lands and established states that "belonged" to them. In some cases they excluded and displaced local population, killed them, or removed them to delimited areas; sometimes these populations were granted formal unequal legal status (Fredrickson, 1997; Mann, 2005). These are peculiar types of democracy because they draw a sharp line between "the people" who deserve representation and the "non-people" who are not represented and denied basic rights.

Paraphrasing Brubaker (1996), these are extreme cases of simultaneously nationalizing and de-nationalizing states: they nationalize the migrants, who otherwise would have rarely been considered "a nation," and "de-nationalize" the region's original inhabitants, who are obviously not European "national communities," but are reconstructed by the state imposed on them as an excluded and dispossessed social category. The European nation-state constantly erects internal and external borders of distinction to define who is outside the state and who are the Others inside it (Mignolo, 2000). Non-recognition of the local population in settler democracies constitutes symbolic violence, which often deteriorates into increasingly physical violence in order to maintain the regime, at the same time that the democratic institutions are improved for the recognized "nationals" (Mann, 2005).

As argued above, imagination is a vital element of politics; without it, democracy cannot work as a system of representation. However, if parts of the population are excluded from the imagined people and not recognized as equal citizens, democracy is only imagined, as it cannot contain social conflicts by the dynamic opening of political space for mediation. Exclusion and misrecognition are acts of symbolic violence, and in order to maintain the exclusion of a group, the state may use physical violence. The closure of political space to specific groups in democratic states can be achieved formally by the legal system and institutional procedures; it can also be informal, through by everyday behavior, discourse, and language. This is the major political critique suggested by the concept of political space. Chapters 2 and 7 below analyze resistance movements against the closure of political spaces by imposed colonial institutions, while Chapters 3 and 5 discuss struggles against symbolic exclusion and closure of political space to ethnic minorities. Only struggles by the 
working class (Chapters 4 and 6) and the "people" (the 99\% in Chapter 8) were conducted to open political space to social forces given formal democratic institutions and symbolic inclusion within the boundaries of the national community.

\section{Political Actors and Democratic Closure of Political Space}

Here is the dynamic feature of political spaces: given recognized borders and some balance of power between rulers and dominated groups, political spaces of representation can be opened in the political arena in order to facilitate peaceful containment of conflicts by negotiation and compromise. The political arena is framed in between the civil society and state institutions, and the political space for mediation is opened between dominant elites and dominated masses. However, the political actors must also bridge the tension between the concrete state institutions and the imagined national community. In short, political actors are mediators of multiple tensions and conflicts, they compete and in order to maintain and expand their power they may not only open political spaces for mediation, but also close them to competitors. Processes opening political space contradict the violent imposition of unilateral will.

Democratic principles, rules, and institutions are designed to consolidate the political arena as a mediator of conflicts within the state and to facilitate the dynamic opening of political spaces of representation by political actors. Securing individual freedoms of speech and association; inclusive, periodic, and open elections between competing parties; building government coalitions and protecting opposition parties (Schmitter and Karl, 1991) - all these are institutional arrangements that encourage the opening of political space to new agendas, identities, discourses, and actors. And while highly democratic constitutions and institutions may be violently eliminated by unilaterally imposed regimes, the concept of political space is designed primarily to comprehend less obvious closures of political space that also take place under democratic rules of the game.

The potential deterioration of formal democratic regimes into what I call "imaginary democracies" has been formulated by O'Donnell (1992, 1996) in different terms in his critique of apparently "consolidated" 
democracies in Latin America. The primary concern of the literature of transition to democracy was consolidation, namely long-term maintenance of democratic rules of the game, and the changing of governments by election without coups. After consolidation has been achieved, the questions focus on the failure of the newly formalized democratic regimes to contain social conflicts by means of recognition, representation, mediation, and compromise. In other words, the question is when and why political spaces for the containment of social conflicts by representation are opened, and when and how they might be closed by dominant political actors seeking to maintain their power and close the spaces for competition. These are core questions of the present research project.

The fact that democracy may not work despite the consolidation of formal rules of the game has produced a huge typology of "limited" democracies and democratic "deficits" (Collier and Levitsky, 1997). Although designed to describe specific forms that prevent the opening of political space, my interest is not in classification but in providing a tool for the analytical critique of political practices that prevent representation of social conflicts, the opening of new agendas, and the entry of new political actors. This is not a particular problem of new and deficient democratic regimes but a built-in deficiency of democracy due to its potential illusionary aspect.

Political actors often try to close political space to new competing actors precisely due to the lack of autonomy and stability that characterizes the political arena and its dependency on the support of social forces. In other words, the dynamic character of political spaces has a double meaning for political actors: the chance to increase power and the risk of losing it. Given the uncertainty built into the political arena, political actors-leaders and parties - seek to secure their positions by a wide variety of institutional and discursive means. Both are usually mutually supportive and are designed to establish durable links between political actors and the two potentially autonomous factors that determine the lack of autonomy of political society: state institutions and civil social forces. This comparative research project is also aimed to uncover both discursive and institutional means used by political actors aiming to maintain their power. 


\section{ReSISTANCE Mo(Ve)MENTS}

Analyzing resistance is essential to expanding the concept of political space, because it presents the reaction of a subjugated group to the closure of political space. In order to open political space, subjugated social groups must make collective demonstrations of presence aiming at bringing to an end the hidden (symbolic) violence of their non-recognition. This is why the collective actions of subjugated groups are always acts of presence, and no matter if they are more or less violent-or even non-violent-they might provoke violent reactions by the dominant (Fredrickson, 1997: Ch. 10). However, as argued above, the use of violence is in itself a sign that the dominant group is losing political power, and it may lead either to the opening of political space or to the escalation of violence.

Resistance is the counterpart of symbolic violence. Both are mixed types of the opposite properties of violence and political power: resistance is a physical presentation of power by subordinated groups (similar to violence) seeking symbolic recognition (similar to politics), while symbolic violence is a representation of superior power of the dominant (similar to politics) used to submit a group by means of non-recognition, humiliation and degradation (similar to violence). Contrary to physical violence, symbolic violence is a more sophisticated and effective form of domination; likewise, resistance is a more sophisticated form of struggle.

The interrelations between symbolic violence and resistance are the everyday form of power relations and power struggles between dominant and dominated groups, while the opening of political space is the peaceful way to contain social conflicts. On the one hand when facing resistance the dominant can afford to ignore it, given sufficient confidence in their power; react violently when they are less confident; or recognize the subordinated and negotiate a compromise, namely open up political space having realized the ineffectiveness or immorality of violent repression. On the other hand, the subordinated cannot use symbolic violence because they cannot ignore the power used against them by the dominant. After presenting their power in the public sphere they may empower their representatives to speak in their name upon recognition, or may intensify their resistance.

The most extreme cases of resistance occur when organized violence is escalated by both sides, taking the form of a "war" where the victory of 
one is the other's defeat. When the dominant group succeeds, this could mean authoritarian rule at best, and displacement, mass murder, or genocide at worst (Mann, 2005). Complete victory by the subordinated group means violent takeover and removal of the previous rulers. Such scenarios include civil society revolutions installing democracy instead of the authoritarian regime, national liberation revolutions installing local leadership instead of colonial rule, and class revolutions replacing the dominant class (Tilly, 1993; Skocpol, 1980). The intention here is to investigate instances of resistance that do not lead to escalation of violence, war, and unilateral victory, but to varied degrees of recognition and representation by opening political spaces to subordinated social forces.

My suggested definition of resistance is the attempt to open political space through physical presentation of power by subordinated social forces seeking recognition and representation. This resistance can be understood as a movement because it mobilizes social forces over a long period, creating a relation between the timeframe and collective action which constitutes the mo(ve)ment. The elements of the theoretical framework of dynamic political spaces developed from one research project to the other, as described in the Prologue, and led to the questions at the core of the present project: What are the social forces involved in resistance? What do they resist and why? What are the differential effects of resistance movements? What are their immediate and longterm achievements and failures? The investigation of resistance also led to the most critical question: What are the repertoires of subjugation used by the dominant political actors aiming at neutralizing resistance?

Movements and moments are intertwined, hence the term mo(ve) ment. The moment refers to the timeframe between the initial intrusion into the public sphere, when the movement mobilizes collective action and succeeds in making the group visible. At that point in time, collective identity and claims are defined and publicly discussed by social activists, opinion leaders and political actors. In principle, the moment of resistance can be short or prolonged; in the cases analyzed here, the timeframes range from one month of ethnic riots (April 1959) to five years of working class strikes (1960-1965) and Palestinian national revolt (1987-1992). The moment ends when the movement, its agendas, claims and ideas no longer attract public interest after the problem is considered to have been solved, with the group legitimately represented or successfully marginalized by political or state actors. 
In what follows, each chapter is dedicated to a particular resistance mo(ve)ment, following the same analytical framework. I start with a background description and analysis of the construction of dominant power and subjugation of a specific social group, aiming to understand the mo(ve)ment's context. The analysis of the initial intrusion into the public sphere is important in order to understand how dominant groups react to it-by recognition or repression or some combination of both. The dynamics of recognition or repression, success or failure, will help us understand the sources of power wielded by the dominant compared to the dominated social groups.

The analysis of each mo(ve)ment's duration will help us understand the autonomous sources of power of the resisting social groups, and also the threat they present to the rulers. Public dissolution of the mo(ve) ment does not necessarily spell its political end, and I discuss why specific movements lost momentum, became marginalized and eventually disappeared. I then analyze their aftermath, in which powerful groups react to the movement in what I term counter-mo(ve)ment.

Similarly to the movement, the timeframe of the counter-mo(ve) ment varies from a few months to several years. In all cases, it is an attempt by dominant groups and rulers to reestablish their powerful position by redefining agendas, discourses, institutions and structures. The counter-mo(ve)ment, however, is never a return to the status quo ante but a re-accommodation of the political arena by either attempting to shrink the space opened by the mo(ve)ment (never to become totally closed ever again), coopting its leaders or taking other steps to regain control over the now open political space. The goal of the countermo(ve)ment is to prevent future eruption of a new resistance mo(ve) ment. It does not always succeed, and when it does, its success is often partial. Accordingly, each chapter will present the historical background of the resistance mo(ve)ment, its lifecycle and counter-mo(ve)ment.

\section{Between Social Actors ANd Social Movements}

The concept of mo(ve)ments refers to the peculiar intersection of the movement and moment of mass mobilization, and is designed to distinguish these movements both from the best known concepts of social movement research-“cycles of protest" (Tarrow, 1989) and "political 
opportunities structure" (Eisinger, 1973; Tilly, 1978; McAdam, 1996). This book discusses the time framing (moment) of resistance movements, aiming to comprehend the historical contingencies that empower specific social identities and explore why political opportunities are opened, and what caused the weakening of the dominant powers, aiming to analyze the linkage between the moment and movement.

Mo(ve)ments of resistance differ from social movements in several aspects. The moment does not occur in the middle of the "curve" between closed and open political opportunities (Eisinger, 1973; Tilly, 1978; McAdam, 1996); it is rather a matter of almost complete closure of legitimate channels of representation. The "political" aspect of the opportunity is not just a matter of structural, institutional or formal politics, but also a matter of symbolic repression of identities, narratives, discourses and agendas. This is the reason why we must study and comprehend the local conditions of the specific case (Kriesi et al., 1995), the social conflicts and tools used by the dominant groups to maintain their power, and the sequence of events that provoke the political dynamics of protest, including the influence of international factors.

Movements of resistance seek to gain recognition and representation of their claims, and protest against the dominant power, as well as against the entire political system, including the opposition, for failing to represent the claims of the oppressed (Snow, 2004). The mo(ve)ment of resistance is not necessarily the culmination of any long-term action by social activists and organizers but a volcanic eruption of repressed discontent that suddenly finds a way up to the public surface. It is not a cycle (Tarrow, 1989), however, because when the moment ends the institutionalized political actors threatened by the movement react to prevent a new cycle. I call this reaction counter-mo(ve)ment because the resistance mo(ve)ment has always some effect-whether in the short, middle or long term - which does not necessarily represent its original claims; it rather has unintended consequences, provoking in some cases the completely opposite reaction. Here my analysis departs from the social movement literature that usually assumes various positive outcomes, including the institutionalization of social protest and actors, and even actual change in government policies (Tarrow, 1998; McAdam, 1996; Meyer, 2004).

Although the concept of resistance movements suggested here differs from social movements, there is some overlap. Both types of move- 
ments are framed by significant historical moments of beginning and ending, and both mobilize social forces. While resistance movements are physical presentations of power in the absence of political space for recognition and representation of a specific group, social movements may represent agendas and issues with no necessary mass mobilization supporting them, and often tend to institutionalize and establish links with political actors.

The overlapping occurs when social and resistance movements have both features: as resistance movements they physically express the power of misrepresented subordinated social groups; and as social movements they also have clear identities and names decided by social actors who formally set forth who they are and what they want. I discuss two such cases in this book: the Israeli Black Panthers (1971-1973) and Forum/13 (1980). The interesting common denominator of the overlapping cases is that the social actors continued arguing that the movement was still alive after the moment of resistance had passed, and when they had lost the capacity to mobilize their constituencies.

In cases of resistance without a social movement, the memory of the event takes on a dual meaning. On the one hand, formal narratives tend to marginalize or even neglect these events. On the other hand, the ideas and agendas invoked in those mo(ve)ments often reemerge in the future. Thus, the 1959 Wadi Salib riots inspired the Black Panthers in 1971; the working class revolt in 1960-65 inspired Forum/13; and the Intifada of 1987-92 inspired the Second Intifada in 2000. The next Chapter focuses on the peculiar phenomenon of "historical amnesia," questioning exactly why there is absolutely no memory or legacy of the successful 1931 Jewish-Arab anti-colonial strike.

\section{CONCLUSION}

This book proposes a theoretical framework designed to uncover, analyze and criticize the repression of subordinated social forces under either military or colonial rule, and also within legitimate democratic rules of the game. The historical chapters analyze the context of political domination and exclusion that facilitates the emergence of the mo(ve) ment of resistance. In the concluding chapter, I suggest some generalizations related to the various forms of resistance and their success in 
opening political space, as well as to the repertoire of options available to the dominant groups seeking to shrink the political space of subordinated masses and roll back their achievements in the aftermath.

Each chapter attempts to solve a crucial historical puzzle through the analysis of a mo(ve)ment of resistance, no matter how marginal and short-lived. The most telling in this sense is Chapter 2, which seeks to comprehend the ethno-national conflict between Jews and Arabs and its tragic deterioration into the forced migration of Palestinians in 1948 by analyzing a joint anti-colonial strike that succeeded in reducing government transportation levies in 1931. Chapter 3 seeks to fathom the strange phenomenon of a so-called Labor party which actually represented the Ashkenazi (European Jewish) middle classes by analyzing the repression of Mizrahi (Middle-Eastern Jewish) ethnic riots of 1959. Next, Chapter 4 analyzes the working-class revolt during the period of full employment (1960-1965) in an attempt to explain why the Labor Party institutionalized the occupation of the West Bank and Gaza Strip and the integration of the Palestinians into Israeli economy as a captive market under military rule. Chapter 5 analyzes the Israeli Black Panthers movement, looking for the sources of ethno-class mobilization of the "left" against the "right" among the Israeli electorate, and the complete sweeping of all socioeconomic, cultural, and political issues under the tribal carpet. Chapter 6 conceptualizes the political economy of hyperinflation and its management through the imposition of neoliberal policies and structures by analyzing the struggle of powerful workers to protect their privileged status. The following chapter analyzes Israel's ability to maintain its military control over the Palestinians by looking into the Intifada resistance mo(ve)ment (1987-1993) and its relative limited success in establishing the Palestinian Authority (PA) under continued Israeli domination. Finally, Chapter 8 discusses the unprecedented mass mobilization of civil society against the capital-state linkage in the name of "the people" and uses previous conceptualizations of political repertoires of distortion to analyze the 2013 electoral campaign.

On the whole, the book discusses the tremendous obstacles of the Israeli polity, preventing the opening of political space to the representation of the working class, Mizrahi Jews and Palestinians. The comprehensive analysis offered below suggests that Israel is an imaginary or illusionary democracy, namely a regime that effectively closes political space 
to subordinated groups. It is effective precisely owing to its success in legitimizing itself as a democracy, both locally and internationally. The repressive features of Israeli democracy, however, are not unique. They occur in various forms in all democratic regimes, enabling them to close political space to subordinated groups, as witnessed in the 2011 Occupy movements in Europe, Latin America, Israel and the US, that followed the Arab Spring. The Israeli case, however, stands out in terms of its variety of forms and cases, helping me formulate, elaborate, and expand the theoretical framework of dynamic political spaces. 